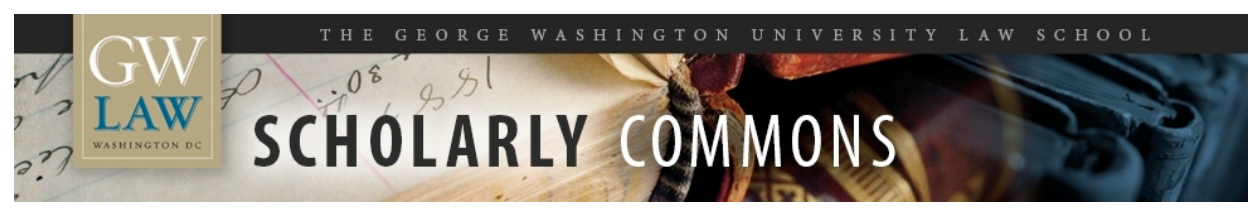

\title{
The Identification of Customary International Law and Other Topics: The Sixty-Seventh Session of the International Law Commission
}

Sean D. Murphy

George Washington University Law School, smurphy@law.gwu.edu

Follow this and additional works at: https://scholarship.law.gwu.edu/faculty_publications

Part of the Law Commons

\section{Recommended Citation}

Suggested citation: Murphy, Sean D., The Identification of Customary International Law and Other Topics: The Sixty-Seventh Session of the International Law Commission, American Journal of International Law (forthcoming 2015-16).

This Article is brought to you for free and open access by the Faculty Scholarship at Scholarly Commons. It has been accepted for inclusion in GW Law Faculty Publications \& Other Works by an authorized administrator of Scholarly Commons. For more information, please contact spagel@law.gwu.edu. 


\title{
CURRENT DEVELOPMENTS
}

\section{IDENTIFICATION OF CUSTOMARY INTERNATIONAL LAW AND OTHER TOPICS: THE SIXTY-SEVENTH SESSION OF THE INTERNATIONAL LAW COMMISSION}

\author{
By Sean D. Murphy*
}

\section{(forthcoming American Journal of International Law)}

The International Law Commission held its sixty-seventh session in Geneva from May 4 to June 5, and from July 6 to August 7, 2015, under the chairmanship of Narinder Singh (India). ${ }^{1}$ Notably, the Commission's drafting committee completed a full set of sixteen draft conclusions on the topic of "identification of customary international law," paving the way for those conclusions with commentaries to be approved by the Commission on first reading in 2016.

Additionally, the Commission provisionally adopted with commentaries initial draft guidelines on "protection of the atmosphere" and initial draft articles on "crimes against humanity," as well as one further draft conclusion with commentary on "subsequent agreements and subsequent practice in relation to the interpretation of treaties." Progress was also made in developing draft principles on "protection of the environment in relation to armed conflicts," draft articles on "immunity of State officials from foreign criminal jurisdiction," and draft guidelines on "provisional application of treaties." The Commission completed its work on the topic "the most-favored-nation clause" and decided to add a new topic of jus cogens to its agenda.

\section{IDENTIFICATION OF CUSTOMARY INTERNATIONAL LAW}

The Commission debated at the sixty-seventh session the third report of the special rapporteur on this topic, Sir Michael Wood (United Kingdom), ${ }^{2}$ which proposed both new conclusions and revisions to a few of the conclusions previously adopted within the drafting committee. ${ }^{3}$ The Commission's drafting committee then completed work on a set of sixteen draft conclusions. Wood will now prepare commentaries to the sixteen conclusions with the expectation that the conclusions with commentaries will be approved by the Commission on first reading in 2016 (a second reading, to complete the project, could then occur in 2018). The sixteen draft conclusions read as follows:

\footnotetext{
* Patricia Roberts Harris Research Professor of Law, George Washington University, and member of the UN International Law Commission. My thanks to Laura Withers (JD '16) for assistance in preparing this essay.

${ }^{1}$ See Report of the International Law Commission on the Work of Its Sixty-Seventh Session, UN GAOR, 70th Sess., Supp. No. 10, at 9, para. 4, UN Doc. A/70/10 (2015) [hereinafter 2015 Report]. This report and other ILC documents are available online at http://legal.un.org/ilc/.

${ }^{2}$ International Law Commission, Third Report on Identification of Customary International Law, UN Doc. A/CN.4/682 (Mar. 27, 2015) (prepared by Special Rapporteur Michael Wood) [hereinafter Third Report on Identification of Customary International Law].

${ }^{3}$ Id. at 69-70. For discussion of prior work on these draft conclusions, see Sean D. Murphy, The Expulsion of Aliens (Revisited) and Other Topics: The Sixty-Sixth Session of the International Law Commission, 109 AJIL 125, 140-42 (2015) [hereinafter Murphy, Sixty-Sixth Session].
} 


\section{PART ONE - INTRODUCTION}

\section{Draft Conclusion 1}

Scope

The present draft conclusions concern the way in which the existence and content of rules of customary international law are to be determined.

PART TWO - BASIC APPROACH

Draft Conclusion 2

Two constituent elements

To determine the existence and content of a rule of customary international law, it is necessary to ascertain whether there is a general practice that is accepted as law (opinio juris).

Draft Conclusion 3

Assessment of evidence for the two elements

1. In assessing evidence for the purpose of ascertaining whether there is a general practice and whether that practice is accepted as law (opinio juris), regard must be had to the overall context, the nature of the rule, and the particular circumstances in which the evidence in question is to be found.

2. Each element is to be separately ascertained. This requires an assessment of evidence for each element.

PART THREE - A GENERAL PRACTICE

Draft Conclusion 4

Requirement of practice

1. The requirement, as a constituent element of customary international law, of a general practice means that it is primarily the practice of States that contributes to the formation, or expression, of rules of customary international law.

2. In certain cases, the practice of international organizations also contributes to the formation, or expression, of rules of customary international law.

3. Conduct of other actors is not practice that contributes to the formation, or expression, of rules of customary international law, but may be relevant when assessing the practice referred to in paragraphs 1 and 2 .

Draft Conclusion 5

Conduct of the State as State practice 
State practice consists of conduct of the State, whether in the exercise of its executive, legislative, judicial or other functions.

Draft Conclusion 6

Forms of practice

1. Practice may take a wide range of forms. It includes both physical and verbal acts. It may, under certain circumstances, include inaction.

2. Forms of State practice include, but are not limited to: diplomatic acts and correspondence; conduct in connection with resolutions adopted by an international organization or at an intergovernmental conference; conduct in connection with treaties; executive conduct, including operational conduct "on the ground"; legislative and administrative acts; and decisions of national courts.

3. There is no predetermined hierarchy among the various forms of practice.

\section{Draft Conclusion 7}

Assessing a State's practice

1. Account is to be taken of all available practice of a particular State, which is to be assessed as a whole.

2. Where the practice of a particular State varies, the weight to be given to that practice may be reduced.

Draft Conclusion 8

The practice must be general

1. The relevant practice must be general, meaning that it must be sufficiently widespread and representative, as well as consistent.

2. Provided that the practice is general, no particular duration is required.

PART FOUR -ACCEPTED AS LAW (OPINIO JURIS)

Draft conclusion 9

Requirement of acceptance as law (opinio juris)

1. The requirement, as a constituent element of customary international law, that the general practice be accepted as law (opinio juris) means that the practice in question must be undertaken with a sense of legal right or obligation.

2. A general practice that is accepted as law (opinio juris) is to be distinguished from mere usage or habit. 
Draft conclusion 10

Forms of evidence of acceptance as law (opinio juris)

1. Evidence of acceptance as law (opinio juris) may take a wide range of forms.

2. Forms of evidence of acceptance as law (opinio juris) include, but are not limited to: public statements made on behalf of States; official publications; government legal opinions; diplomatic correspondence; decisions of national courts; treaty provisions; and conduct in connection with resolutions adopted by an international organization or at an intergovernmental conference.

3. Failure to react over time to a practice may serve as evidence of acceptance as law (opinio juris), provided that States were in a position to react and the circumstances called for some reaction.

\section{PART FIVE - SIGNIFICANCE OF CERTAIN MATERIALS FOR THE IDENTIFICATION OF CUSTOMARY INTERNATIONAL LAW}

Draft conclusion 11

Treaties

1. A rule set forth in a treaty may reflect a rule of customary international law if it is established that the treaty rule:

(a) codified a rule of customary international law existing at the time when the treaty was concluded;

(b) has led to the crystallization of a rule of customary international law that had started to emerge prior to the conclusion of the treaty; or

(c) has given rise to a general practice that is accepted as law (opinio juris), thus generating a new rule of customary international law.

2. The fact that a rule is set forth in a number of treaties may, but does not necessarily, indicate that the treaty rule reflects a rule of customary international law.

Draft conclusion 12

Resolutions of international organizations and intergovernmental conferences

1. A resolution adopted by an international organization or at an intergovernmental conference cannot, of itself, create a rule of customary international law.

2. A resolution adopted by an international organization or at an intergovernmental conference may provide evidence for establishing the existence and content of a rule of customary international law, or contribute to its development. 
3. A provision in a resolution adopted by an international organization or at an intergovernmental conference may reflect a rule of customary international law if it is established that the provision corresponds to a general practice that is accepted as law (opinio juris).

Draft conclusion 13

Decisions of courts and tribunals

1. Decisions of international courts and tribunals, in particular of the International Court of Justice, concerning the existence and content of rules of customary international law are a subsidiary means for the determination of such rules.

2. Regard may be had, as appropriate, to decisions of national courts concerning the existence and content of rules of customary international law, as a subsidiary means for the determination of such rules.

Draft conclusion 14

Teachings

Teachings of the most highly qualified publicists of the various nations may serve as a subsidiary means for the determination of rules of customary international law.

PART SIX - PERSISTENT OBJECTOR

Draft conclusion 15

Persistent objector

1. Where a State has objected to a rule of customary international law while that rule was in the process of formation, the rule is not opposable to the State concerned for so long as it maintains its objection.

2. The objection must be clearly expressed, made known to other States, and maintained persistently.

PART SEVEN - PARTICULAR CUSTOMARY INTERNATIONAL LAW

Draft conclusion 16

Particular customary international law

1. A rule of particular customary international law, whether regional, local or other, is a rule of customary international law that applies only among a limited number of States. 
2. To determine the existence and content of a rule of particular customary international law, it is necessary to ascertain whether there is a general practice among the States concerned that is accepted by them as law (opinio juris). ${ }^{4}$

These draft conclusions focus on the most significant issues with respect to identification of customary international law and Wood anticipates the Commission adopting relatively brief commentaries to accompany them. Even so, the draft conclusions contain certain formulations that no doubt will elicit the attention of states and others; a few of those are suggested below.

Inaction as practice and/or evidence of acceptance as law. The degree to which a state's inaction may constitute practice and/or serve as acceptance as law is addressed in draft conclusion 6, paragraph 1 , and draft conclusion 10, paragraph 3 , where important qualifying language appears. In the former, the words "under certain circumstances" serve to caution that only deliberate inaction may be considered relevant practice. In the latter, rather than using the term "inaction," the paragraph speaks of a "failure to react over time" to the practice of others, in a situation where the state was "in a position to react" and "the circumstances called for some reaction." States will no doubt scrutinize such language carefully to see whether it properly allows for custom to be identified in situations where affirmative conduct by many states cannot be observed, while at the same time sufficiently protects states from inadvertently and erroneously being seen to accept a developing customary rule. In his third report, the special rapporteur discusses and elaborates upon such conditions, noting that "the relevant practice ought to be one that affects the interests or rights of the State failing or refusing to act," must have had actual knowledge of the practice in question, ${ }^{6}$ and the inaction must have been "maintained over a sufficient period of time.",

Practice of international organizations. Draft conclusion 4, paragraph 1, maintains the centrality of states in "practice" that contributes to the formation, or expression, of rules of customary international law, as do other conclusions that repeatedly refer to "States." At the same time, draft conclusion 4, paragraph 1, asserts only that it is "primarily" the practice of States" that is relevant, leaving open the door to practice by international organizations. Indeed, paragraph 2 recognizes (using similar language) that, '[i]n certain cases', the practice of international organizations, too, contributes to the formation, or expression, of rules of customary international law.

Certain ways that international organizations make such a "contribution" appear obvious. First, "acts of international organizations may reflect the practice and convictions of their member States," meaning that the conduct of states when they appear before an international organization may "be State practice or evidence of opinio juris." "Second, "the conduct of

\footnotetext{
${ }^{4}$ International Law Commission, Statement of the Chairman of the Drafting Committee, Mr. Mathias Forteau, "Identification of Customary International Law," annex (July 29, 2015), available at http://legal.un.org/docs/?path=../ilc/documentation/english/statements/2015_dc_chairman_statement_cil.pdf\&lang= EF.

${ }^{5}$ Third Report on Identification of Customary International Law, supra note 2, at 12, para. 23.

${ }^{6} I d$. at 13 , para. 24.

${ }^{7} I d$. at 14 , para. 25 .

${ }^{8} I d$. at 51, para. 74.
} 
international organizations may serve to catalyse State practice." ${ }^{9}$ Thus, for example, a major public statement by the UN Secretary-General that international humanitarian law requires that states refrain from using a certain type of weapon might well encourage states to follow a general practice accepted as law in that regard. Such propositions are consistent with the case law of the International Court, such as in the Military and Paramilitary Activities case ${ }^{10}$ and the Nuclear Weapons advisory opinion, ${ }^{11}$ where the Court was focused on the practice of states before international organization. Such propositions are also consistent with views stated by scholars, who typically stress that it is the practice of states before the international organization, as demonstrated by vote counts, and the reasons given by states for casting their votes, which is important when determining the existence of customary rules. ${ }^{12}$

By contrast, a third proposition set forth in the special rapporteur's third report is less substantiated. Here, the claim is that the practice of international organizations "may, as such, serve as relevant practice for purposes of formation and identification of customary international law." ${ }^{13}$ There is no jurisprudence from the International Court or from other international courts or tribunals, including administrative tribunals, cited in the third report in support of this proposition. Numerous scholarly writings are cited, but a review of those writings uncovers little in the way of supporting references. ${ }^{14}$

\footnotetext{
${ }^{9} I d$. , para. 75 .

${ }^{10}$ In the Nicaragua v. United States case, in the context of considering the opinio juris element, the Court focused "with all due caution" on the practice of States in relation to certain General Assembly resolutions, finding that it was not the resolution itself which establishes opinio juris but, rather, it was the consent to or rejection of the resolution by States which demonstrated their attitude toward the rule announced in the resolution. Military and Paramilitary Activities in and Against Nicaragua (Nicar. v. U.S.), 1986 ICJ REP. 14 (June 27), at 99-100, paras. 188-90.

${ }^{11}$ Similarly, in the Nuclear Weapons advisory opinion, the Court was not focused on the fact that the General Assembly on numerous occasions had adopted resolutions but, rather, on the practice of States in relation to such resolutions. For the Court, "it is necessary to look at its content and the conditions of its adoption; it is also necessary to see whether an opinio juris exists as to its normative character. Or a series of resolutions may show the gradual evolution of the opinio juris required for the establishment of a new rule." Ultimately, the Court rejected claims that the resolutions established a particular rule, given that several of these resolutions were "adopted with substantial numbers of negative votes and abstentions...." Legality of the Threat or Use of Nuclear Weapons, 1996 ICJ REP. 226 (July 8), at 254-55, paras. 70-71.

${ }^{12}$ See Jan Wouters \& Philip De Man, International organizations as law-makers, in RESEARCH HANDBOOK ON THE LAW OF INTERNATIONAL ORGANIZATIONS 190, 208 (Jan Klabbers \& Asa Wallendahl eds., 2011) (“One should...be mindful not to equate the practice of international organizations with state practice."); Michael Akehurst, The Hierarchy of the Sources of International Law, 47 BRIT. Y.B. INT'L L. 273, 281 (1976) (noting that such acts "are merely part of the practice from which customary international law develops, or...merely record agreements between (or promises by) States."); see also Julio A. Barberis, "Les résolutions des organisations internationales en tant que source du droit des gens," in RECHT ZWISCHEN UMBRUCH UND BEWAHRUNG 21, 22 (Ulrich Beyerlin et al.

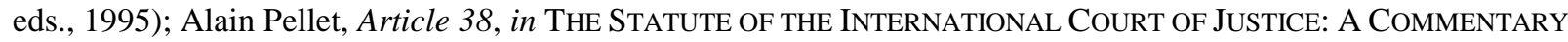
677, 752, 761 (Andreas Zimmermann et al. eds., 2d ed., 2012).

${ }^{13}$ Third Report on Identification of Customary International Law, supra note 2, at 52, para. 76 (emphasis added). ${ }^{14}$ Id., nn.179-82. Some of these writings cite to the International Court's Reservations to the Genocide Convention advisory opinion, but there the Court found the opposite; it declined to recognize that the practice of an international organization established a general rule. See Reservations to the Convention on the Prevention and Punishment of the Crime of Genocide, 1951 ICJ REP. 15 (May 28), at 25. Likewise, some of these writings cite to the Commission's prior work, see, e.g., Gennady M. Danilenko, The Theory of International Customary Law, 31 GER. Y.B. INT'L L. 9, 21 (1988), but a close reading of that work only reveals support for the first two propositions, not the third. See, e.g., Report of the International Law Commission on the Work of Its Second Session, UN GAOR, 5th Sess., Supp. No. 12, at 372, para. 78, UN Doc. A/CN.4/34 (1950) [hereinafter 1950 Report] (finding that "[r]ecords of the cumulating
} 
The "most clear-cut" example cited by the third report concerns the situation where states have assigned their competences to an international organization, such as to the European Union, for here "such practice may be equated with the practice of States." ${ }^{\text {"S }}$ Such an example may well be valid, though the European Union is a rather unique international organization (often described more as a "supra-national" organization), and thus may not be exemplary of international organizations generally. The European Union itself asserted to the General Assembly's Sixth Committee (Legal) in 2014 that it is "[i]n areas in which, in accordance with the rules of the European Union treaties, only the Union could act, such as trade or fisheries matters" that the Union's practice should "be taken into account with regard to the formation of customary international law alongside the implementation by the member States of European Union legislation." "16 This focus on the EU's practice only in areas of its exclusive competence suggests an emphasis solely on acts by the European Union that are state-like and is consistent with the statements made by Norway (on behalf of the Nordic countries), ${ }^{17}$ Spain, ${ }^{18}$ France, ${ }^{19}$ Portugal, ${ }^{20}$ and Singapore ${ }^{21}$ in the Sixth Committee.

After noting that some doubts had been expressed in the Commission about this third proposition, the special rapporteur - in his statement summing up the Commission's debate on the topic - indicated that a

specific example is the European Bank for Reconstruction and Development's Standard Terms and Conditions for loan, guarantee and other financing agreements, which recognize that the sources of public international law that may be applicable in the event of dispute between the Bank and a party to a financing agreement include, inter alia, "...forms of international custom, including the practice of states and international financial institutions of such generality, consistency and duration as to create legal obligations." 22

The Commission has in the past sought to codify or progressively develop rules particular to international organizations in their relations with states or with other international organizations, as may be seen in the draft articles that became the 1986 Vienna Convention on the Law of Treaties between States and International Organizations or between International

practice of international organizations may be regarded as evidence of customary international law with reference to States' relations to the organizations.") (emphasis added).

${ }^{15}$ Third Report on Identification of Customary International Law, supra note 2, at 53, para. 77.

${ }^{16}$ UN GAOR, 69th Sess., 25th mtg. at 13, para. 79, UN Doc. A/C.6/69/SR.25 (Nov. 28, 2014) (statement of the European Union).

${ }^{17}$ Id. at 20, para. 130 (statement of Norway on behalf of the Nordic countries).

${ }^{18}$ UN GAOR, 69th Sess., 26th mtg. at 18, para. 102, UN Doc. A/C.6/69/SR.26 (Nov. 20, 2014) (statement of Spain).

${ }^{19}$ UN GAOR, 69th Sess., 22d mtg. at 7, para. 30, UN Doc. A/C.6/69/SR.22 (Nov. 22, 2014) (statement of France).

${ }^{20}$ UN Doc. A/C.6/SR.26, supra note 18, at 2, para. 3 (statement of Portugal).

${ }^{21} \mathrm{Id}$. at 12, para. 65 (statement of Singapore).

${ }^{22}$ Statement of Sir Michael Wood, Special Rapporteur, Summing up the Debate on the Third Report on Identification of Customary International Law, para. 27 (May 21, 2015) (citing to European Bank for Reconstruction and Development, Standard Terms and Conditions, § 8.04(b)(vi)(C) (Dec. 1, 2012)) (emphasis in original). 
Organizations, ${ }^{23}$ and the 2011 draft articles on the responsibility of international organizations. ${ }^{24}$ The extent to which those rules reflect settled customary international law is not clear and the reception of such rules by states and by international organizations has been muted (the 1986 Vienna Convention is still not in force, while the 2011 draft articles do not appear likely to become a convention). In any event, such projects suggest an approach by the Commission previously that separates rules relating to states from rules relating to international organizations, not a mixing of the two into a single system.

To the extent that the practice of international organizations, as such, contributes to the formation of customary international law, the special rapporteur's reports to date suggest various limitations which may ultimately work their way into the Commission's commentaries. First, only the external practice of the international organization is relevant - in other words, the practice of the international organization vis-à-vis states or other international organizations. ${ }^{25}$ Second, the practice of organs or other bodies composed of representatives of states is relevant, not the practice of organs composed of independent experts. ${ }^{26}$ Third, some weight may be given to the practice of secretariats, but the greater weight is to be given to practice of intergovernmental organs. ${ }^{27}$ Fourth, the more member states that an international organization has, the greater the weight to be attributed to the practice of that international organization. ${ }^{28}$ Fifth, only the "acts of international organizations on which states have conferred authority" may contribute to the formation, or expression, of rules of customary international law "in the fields in which those organizations operate." ${ }^{29}$ As the International Court has noted:

international organizations...do not, unlike States, possess a general competence. International organizations are governed by the "principle of speciality", that is to say, they are invested by the States which create them with powers, the limits of which are a function of the common interests whose promotion those States entrust to them. ${ }^{30}$

This principle of speciality presumably also applies to any law-making functions of international organizations relating to customary international law, a view endorsed by several states in the Sixth Committee in 2014. ${ }^{31}$ This limitation also helps to explain why it is that conduct by other

\footnotetext{
${ }^{23}$ Report of the International Law Commission on the Work of Its Thirty-Fourth Session, UN GAOR, 37th Sess., Supp. No. 10, at 9, UN Doc. A/37/10 (1982).

${ }^{24}$ Report of the International Law Commission on the Work of Its Sixty-Third Session, UN GAOR, 66th Sess., Supp. No. 10, at 54, UN Doc. A/66/10 (2011).

${ }^{25}$ See Third Report on Identification of Customary International Law, supra note 2, at 49, para. 72; International Law Commission, Second Report on Identification of Customary International Law, at 29, para. 43, UN Doc. A/CN.4/672 (May 22, 2014) (prepared by Special Rapporteur Michael Wood) [hereinafter Second Report on Identification of Customary International Law].

${ }^{26}$ Second Report on Identification of Customary International Law, supra note 25, para. 43. ${ }^{27}$ Id.

${ }^{28}$ Third Report on Identification of Customary International Law, supra note 2, at 50, para. 73.

${ }^{29}$ Second Report on Identification of Customary International Law, supra note 25, at 29, para. 43; see also Third Report on Identification of Customary International Law, supra note 2, at 53, para. 77.

${ }^{30}$ Legality of the Use by a State of Nuclear Weapons in Armed Conflict, 1996 ICJ REP. 66 (July 8), at 78, para. 25.

${ }^{31}$ UN Doc. A/C.6/69/SR.25, supra note 16, at 20, para. 130 (statement of Norway on behalf of the Nordic countries); UN Doc. A/C.6/69/SR.26, supra note 18, at 2, para. 3 (statement of Portugal); id., at 18, para. 102 (statement of Spain). The EU may have taken a similar approach. UN Doc. A/C.6/69/SR.25, supra note 16, at 13, para. 78 (statement of the European Union) ("the European Union's action was based on the responsibilities that its member States had entrusted it with.”).
} 
actors (see draft conclusion 4, paragraph 3) is not "practice" that contributes to the formation of custom, ${ }^{32}$ for states have not empowered those other actors with a law-making function.

Even with these limitations, however, various important aspects of the practice of international organizations "as such" remain unclear, including:

- Can practice "as such" by an international organization, under certain circumstances, include inaction? In other words, if the Security Council is silent when a state claims that international law allows preemptive uses of military force, is this practice of the United Nations in support of such a rule? Statements in the Sixth Committee in 2015 from Jamaica, ${ }^{33}$ Malaysia, ${ }^{34}$ and Norway on behalf of the Nordic countries ${ }^{35}$ all raised concerns about the weight, if any, to be given to the silence of international organizations in the formation of customary international law.

- Presumably to be relevant the practice by the international organization "as such" must be accepted as law (opinio juris) by that organization. If so, how is the opinio juris of an international organization to be established, a question that the Netherlands posed in the Sixth Committee ${ }^{36}$ The forms of evidence identified in draft conclusion 10, paragraph 2 all relate to states.

- Can inaction by an international organization serve as evidence of acceptance as law (opinio juris) just as it does for states? At present draft conclusion 10, paragraph 3, is limited to states.

- Are states and international organizations all part of a unified system of customary international law? If so, then what exactly does that mean? Presumably it cannot mean that to establish a general practice accepted as law, it is necessary to establish that the practice is "sufficiently widespread and representative" (draft conclusion 8, paragraph 1) among both states and all of the thousands of international organizations, since no one approaches customary international law in that way.

- Does it mean instead that the unified system is "primarily" concerned with the practice of states (draft conclusion 4, paragraph 1), but that "in certain cases" (draft conclusion 4, paragraph 2) particular international organizations must also be considered to determine whether the practice is sufficiently widespread and representative? If so, how does one identify which organizations are relevant to the analysis? Further, does this mean that a practice followed by all states nevertheless might not be sufficiently widespread and representative, given contrary practice by particular international organizations?

- Assuming that sufficiently widespread and representative practice is found, does the ensuing rule bind only states or does it bind both states and those particular international organizations that contributed to the practice? If the former, why should international organizations be able to contribute to the formation of a customary rule to which they are not bound? If the latter, must an international organization that is relevant to the rule

\footnotetext{
32 Third Report on Identification of Customary International Law, supra note 2, at 54, para. 79.

${ }^{33}$ UN GAOR, 69th Sess., 27th mtg. at 7, para. 37, UN Doc. A/C.6/69/SR.27 (Nov. 24, 2014) (statement of Jamaica).

${ }^{34} \mathrm{Id}$. at 8, para. 44 (statement of Malaysia).

${ }^{35}$ UN Doc. A/C.6/69/SR.25, supra note 16, at 20, para. 130 (statement of Norway on behalf of the Nordic countries).

${ }^{36}$ UN Doc. A/C.6/69/SR.26, supra note 18, at 9, para. 50 (statement of Netherlands).
} 
persistently object during its formation so as to avoid its application to the international organization?

- Or are there alternatively (or additionally) two sub-systems of customary rules, with one sub-system regulating solely inter-state conduct and another sub-system regulating relations among international organizations and states? If so, then perhaps for the former the practice must be sufficiently widespread and representative only among states and it only binds states in their inter-state relations, while for the latter the practice must be sufficiently widespread and representative among both states and international organizations and only binds them with respect to their relations with each other.

"Particular" custom. The final draft conclusion on particular custom is also of some interest. To date, the Commission has eschewed the more traditional terms of "regional custom" or "special custom" in favor of "particular custom," viewing it as a useful counter-weight to "general custom." One interesting development is that the conclusion does not envisage geographic proximity for the states engaging in the particular custom, even though the principal precedents to date suggest such a nexus. Thus, the International Court of Justice referred in the Asylum Case to "an alleged regional or local custom peculiar to Latin-American States" so long as " $[\mathrm{t}]$ he Party which relies on a custom of this kind [proves] that this custom is established in such a manner that it has become binding on the other Party." ${ }^{37}$ While the Court recognized such a custom as possible between as few as two states, it also emphasized its geographic nature in the Right of Passage over Indian Territory case, when it said that "[i]t is difficult to see why the number of States between which a local custom may be established on the basis of long practice must necessarily be larger than two." ${ }^{38}$ Reflecting on such decisions, scholars such as Cassese, Crawford, and Pellet have characterized these rules as "only binding upon States of a certain geographic area or region." ${ }^{39}$ Indeed, some scholars have analyzed this type of law as a regionalized exception within customary international law permitted because of "respect for regional legal traditions." 40

At the same time, there are other scholars who argue for an approach that allows for a rule of customary international law to exist as among any particular grouping of states, no matter how scattered across the globe, and this is the path selected in draft conclusion 16. Under this approach, it would be possible for there to exist a particular rule of custom as between, for example, Argentina, Russia, South Africa, and Thailand, so long as there is a practice among those four states that is accepted by them as law. The special rapporteur's third report does not provide examples of such a rule, raising a question as to whether such a rule as a practical matter could really emerge in the absence of a treaty relationship. In any event, the commentary may need to answer certain questions, such as: Is it enough to ascertain that all four states consistently

\footnotetext{
${ }^{37}$ Asylum Case (Colom. v. Peru), 1950 ICJ REP. 266 (Nov. 20), at 276 (emphasis added).

${ }^{38}$ Case Concerning Right of Passage over Indian Territory (Port. v. India), 1960 ICJ REP. 6 (Apr. 12), at 39 (emphasis added).

39 ANTONIO CASSESE, INTERNATIONAL LAW 163 (2d ed. 2005) (emphasis added); see also JAMES CRAWFORD, BROWNLIE'S PRINCIPLES OF PUBLIC INTERNATIONAL LAW 29 (8th ed. 2012) (noting the existence of customary norms that "may be practised only within a particular region, creating a 'local' customary law"); Pellet, supra note 12, at 762-64 (noting the International Court of Justice's acceptance of "the possibility of custom of a limited geographical scope").

${ }^{40}$ Malcolm N. ShaW, InTERnational Law 65 (7th ed. 2014) (quoting Maritime Delimitation (Eri. v. Yemen), 119 INT'L L. REP. 417, 448).
} 
engage in the practice or is it necessary to ascertain that they engage in the practice only in their relations with each other? Similarly, is it enough to ascertain that all four states view the practice as compelled by law or must it be ascertained that they regard the practice as compelled only as among the four states?

By way of example, assume that 100 states regard immunity from foreign criminal jurisdiction as including immunity from allegations that a sitting head of state committed genocide, while 93 states do not regard the immunity as applicable in the face of such an allegation. Presumably there is no "general" rule of customary international law, since the global practice is inconsistent. Can it be said that there are two rules of "particular" custom, operating as among the two sets of states? Arguably yes, since there is a general practice among the two sets of states that is accepted by them as law, as envisaged in draft conclusion 16. Arguably no, since the two sets of states are engaged in a practice based on what they believe (mistakenly) to be a "general" rule operating as among all states, not based on a rule that only operates as among their particular group. Ultimately, the commentary (if not the conclusion itself) may need to clarify this point.

\section{OTHER TOPICS AdDRESSED DURING THE SIXTY-SEVENTH SESSION}

\section{Protection of the Atmosphere}

The Commission considered the second report on the protection of the atmosphere by the special rapporteur, Shinya Murase (Japan). ${ }^{41}$ The report proposed five draft guidelines relating to "use of terms," "scope of the guidelines," "common concern of humankind," "general obligation of States to protect the atmosphere," and "international cooperation." During the course of the debate, members raised some concerns about these guidelines, such that the third guideline was sent to the drafting committee on the understanding that it would be placed in a preamble, while the fourth guideline was not sent to the drafting committee at all.

The problem with the third draft guideline was that it sought to use the concept of "common concern of humankind" in a legally operative way, but that term has enjoyed very limited use in treaties (appearing only in the preamble of the Climate Change Convention and the Convention on Biological Diversity, both from 1992), and has been interpreted in creative and doubtful ways in the literature. Ultimately, the Commission provisionally adopted a preamble (which is a work-in-progress) that makes a factual statement that protection of the atmosphere is a "pressing concern of the international community as a whole." The report of the chairman of the drafting committee indicates that this phrase

was proposed by the Special Rapporteur to allay the concerns of those members who preferred to avoid the phrase "common concern of humankind", and to choose instead an expression that the Commission itself had used as a criterion for determining which topics should be brought onto its programme of work, as cited in the ILC Yearbooks of

\footnotetext{
${ }^{41}$ See International Law Commission, Second Report on the Protection of the Atmosphere, UN Doc. A/CN.4/681 (Mar. 2, 2015) (prepared by Special Rapporteur Shinya Murase). For prior discussion of this topic, see Murphy, Sixty-Sixth Session, supra note 3, at 139.
} 
1997 and 1998, and from which it was agreed among the members of the Committee that no legal consequences arise on their own. ${ }^{42}$

Consistent with that outcome, the Commission's commentary to the preamble indicates that it "was considered appropriate to express the concern of the international community as a matter of factual statement, and not as a normative statement, as such, of the gravity of the atmospheric problems." 43

The Commission also adopted draft guidelines 1, 2 and 5. Draft guideline 1 is on "use of terms"; term (a) defines the atmosphere, term (b) speaks to transboundary pollution, and term (c) addresses more generalized atmospheric harm, such as depletion of the ozone layer. Draft guideline 1 reads:

For the purposes of the present draft guidelines,

(a) "Atmosphere" means the envelope of gases surrounding the Earth;

(b) "Atmospheric pollution" means the introduction or release by humans, directly or indirectly, into the atmosphere of substances contributing to deleterious effects extending beyond the State of origin, of such a nature as to endanger human life and health and the Earth's natural environment;

(c) "Atmospheric degradation" means the alteration by humans, directly or indirectly, of atmospheric conditions having significant deleterious effects of such a nature as to endanger human life and health and the Earth's natural environment.

Draft Guideline 2 is on "scope of the guidelines." Uncertainty as to whether these "guidelines" ultimately would solely identify legal principles or would be broader in nature led to bracketed text in paragraph 1, while paragraphs 2-4 sought to capture aspects of the "understanding" developed by the Commission in 2013 regarding this topic. ${ }^{44}$ It reads:

1. The present draft guidelines [contain guiding principles relating to] [deal with] the protection of the atmosphere from atmospheric pollution and atmospheric degradation.

2. The present draft guidelines do not deal with, but are without prejudice to, questions concerning the polluter-pays-principle, the precautionary principle, common but differentiated responsibilities, the liability of States and their nationals, and the transfer of funds to developing countries, including intellectual property rights.

\footnotetext{
${ }^{42}$ International Law Commission, Statement of the Chairman of the Drafting Committee, Mr. Mathias Forteau, "Protection of the Atmosphere," at 10-11 (June 2, 2015), available at http://legal.un.org/docs/?path=../ilc/documentation/english/statements/2015_dc_chairman_statement_atmosphere.pd f\&lang=EF.

${ }^{43} 2015$ Report, supra note 1, at 27.

${ }^{44}$ Report of the International Law Commission on the Work of Its Sixty-Fifth Session, UN GAOR, 68th Sess., Supp. No. 10, at 115, para. 168, UN Doc. A/68/10 (2013) [hereinafter 2013 Report].
} 
3. The present draft guidelines do not deal with specific substances, such as black carbon, tropospheric ozone, and other dual-impact substances, which are the subject of negotiations among states.

4. Nothing in the present draft guidelines affects the status of airspace under international law nor questions related to outer space, including its delimitation.

Draft guideline 5 addresses "international cooperation," meaning cooperation among states and with relevant international organizations. It reads:

1. States have the obligation to cooperate, as appropriate, with each other and with relevant international organisations for the protection of the atmosphere from atmospheric pollution and atmospheric degradation.

2. States should cooperate in further enhancing scientific knowledge relating to the causes and impacts of atmospheric pollution and atmospheric degradation. Cooperation could include exchange of information and joint monitoring.

\section{Crimes against humanity}

During the sixty-sixth session in 2014, the Commission moved the topic of crimes against humanity onto the current program of work and appointed Sean D. Murphy (United States; the present author) as special rapporteur. ${ }^{45}$ The syllabus for the topic expressly indicates that the objective is "to draft articles for what would become a Convention on the Prevention and Punishment of Crimes against Humanity." debated the special rapporteur's first report ${ }^{47}$ and then referred its two proposed draft articles to the drafting committee. Ultimately, the Commission approved four draft articles with commentaries. $^{48}$

Draft article 1, on "scope," indicates that the draft articles apply to the prevention and punishment of crimes against humanity. ${ }^{49}$ Draft article 2 sets forth a general obligation from which flow the other obligations in the draft articles, and states: "Crimes against humanity, whether or not committed in time of armed conflict, are crimes under international law, which States undertake to prevent and punish." ${ }^{50}$ Draft article 3 defines crimes against humanity in terms that reproduce Article 7 of the Rome Statute, albeit with three non-substantive changes necessary given the different context in which the definition is used (for example, changing "For the purpose of this Statute" so as to read "For the purpose of the present draft articles"). An

\footnotetext{
${ }^{45}$ Report of the International Law Commission on the Work of Its Sixty-Sixth Session, UN GAOR, 69th Sess., Supp. No. 10, at 265, para. 266, UN Doc. A/69/10 (2014) [hereinafter 2014 Report]; see Murphy, Sixty-Sixth Session, supra note 3, at 145.

${ }^{46}$ See 2013 Report, supra note 44, at 141, para. 3 (annex B).

${ }^{47}$ International Law Commission, First Report on Crimes against Humanity, UN Doc. A/CN.4/680 (Feb. 17, 2015) (prepared by Special Rapporteur Sean Murphy).

${ }^{48} 2015$ Report, supra note 1, at 52-83, para. 117.

${ }^{49} I d$. at 52.

${ }^{50} I d$. at 53 .
} 
additional paragraph 4 was included in draft article 3 stating: "This draft article is without prejudice to any broader definition provided for in any international instrument or national law." 51 The commentary to this paragraph explains that this paragraph "is meant to ensure that the definition of 'crimes against humanity' set forth in draft article 3 does not call into question any broader definitions that may exist in other international instruments or national legislation," 52 such as the International Convention for the Protection of All Persons against Enforced Disappearance, ${ }^{53}$ or in national law.

Draft article 4 addresses prevention of crimes against humanity. It reads:

1. Each State undertakes to prevent crimes against humanity, in conformity with international law, including through:

(a) effective legislative, administrative, judicial or other preventive measures in any territory under its jurisdiction or control; and

(b) cooperation with other States, relevant intergovernmental organizations, and, as appropriate, other organizations.

2. No exceptional circumstances whatsoever, such as armed conflict, internal political instability or other public emergency, may be invoked as a justification of crimes against humanity. ${ }^{54}$

The commentary to draft article 4 explains that this provision is meant to incorporate four elements, all of which are conditioned by the requirement that steps taken in prevention must be "in conformity with international law." First, states are obligated not to directly commit crimes against humanity. ${ }^{55}$ Second, states are obligated to use their best efforts to prevent persons or groups not directly under their control from committing such acts. ${ }^{56}$ Third, states must enact legislative, administrative, judicial or other preventive measures in any territory under their jurisdiction or control, which might include training programs for military or police personal. Such measures must be "effective," meaning that the state must keep them under review and, if they are deficient, improve them through more effective measures. ${ }^{57}$ Fourth, states must cooperate with other states, with relevant intergovernmental organizations, and, as appropriate with other organizations in order to seek to prevent crimes against humanity. ${ }^{58}$

Subsequent Agreements and Subsequent Practice in Relation to the Interpretation of Treaties

${ }^{51}$ Id. at 58 .

52 Id. at 72 .

${ }^{53}$ International Convention for the Protection of All Persons from Enforced Disappearance, Art. 5, Dec. 20, 2006, 2716 UNTS 3.

542015 Report, supra note 1 , at 73.

${ }^{55} \mathrm{Id}$. at 77-78.

${ }^{56} \mathrm{Id}$. at 78-79.

${ }^{57} \mathrm{Id}$. at $79-82$.

${ }^{58}$ Id. at 82-83. 
This topic, originally dealt with by a Study Group of the Commission within the broader topic "Treaties over Time," is in the process of developing conclusions on the proper use of subsequent agreements and subsequent practice for the interpretation of treaties. According to the Commission's provisional commentary, the draft conclusions "are based on the Vienna Convention on the Law of Treaties [("VCLT")], which constitutes the framework for the work on the topic...."59 At the sixty-fifth and sixty-sixth sessions, the Commission adopted a total of ten draft conclusions with commentaries. ${ }^{60}$ At the sixty-seventh session, based on the third report of the special rapporteur, Georg Nolte (Germany), ${ }^{61}$ the Commission adopted a further draft conclusion with commentary focused on subsequent agreements and subsequent practice in the interpretation of a treaty that serves as the constituent instrument of an international organization. Draft conclusion 11 on "Constituent instruments of international organizations" reads as follows:

1. Articles 31 and 32 apply to a treaty which is the constituent instrument of an international organization. Accordingly, subsequent agreements and subsequent practice under article 31, paragraph 3, are, and other subsequent practice under article 32 may be, means of interpretation for such treaties.

2. Subsequent agreements and subsequent practice under article 31, paragraph 3, or other subsequent practice under article 32, may arise from, or be expressed in, the practice of an international organization in the application of its constituent instrument.

3. Practice of an international organization in the application of its constituent instrument may contribute to the interpretation of that instrument when applying articles 31 , paragraph 1 , and 32 .

4. Paragraphs 1 to 3 apply to the interpretation of any treaty which is the constituent instrument of an international organization without prejudice to any relevant rules of the organization. $^{62}$

The commentary explains that paragraph 1 is intended to recognize that the rules on interpretation contained in VCLT articles 31 and 32, including their elements relating to subsequent agreements and subsequent practice, fully apply to a treaty that serves as the constituent instrument of an international organization. ${ }^{63}$ Paragraph 2 , by referencing subsequent agreements and subsequent practice under VCLT article 31, paragraph 3, signals that it is referring to such subsequent agreements and subsequent practice with respect to the states parties to the treaty. The commentary indicates that such subsequent agreements and subsequent practice may arise either from the states parties' reactions to the practice of an international

\footnotetext{
592013 Report, supra note 44, at 12-13 (citing to Vienna Convention on the Law of Treaties, May 23, 1969,1155 UNTS 331, 8 ILM 679). For prior discussion of this topic, see Murphy, Sixty-Sixth Session, supra note 3, at 136.

${ }^{60} 2013$ Report, supra note 44, at 11-12 (conclusions 1-5); 2014 Report, supra note 45, at 169-70 (conclusions 6$10)$.

${ }^{61}$ International Law Commission, Third Report on Subsequent Agreements and Subsequent Practice in Relation to the Interpretation of Treaties, UN Doc. A/CN.4/683 (Apr. 7, 2015) (prepared by Special Rapporteur Georg Nolte).

622015 Report, supra note 1 , at 89 , para. 129.

${ }^{63}$ Id. at $91-96$.
} 
organization or from their conduct in applying the treaty, such as when the states parties vote for a resolution that explicitly or implicitly interprets the treaty. ${ }^{64}$

Paragraph 3, by contrast, is referring to the practice of the international organization itself in applying the treaty. Such practice does not fall within VCLT article 31, paragraph 3, but rather under VCLT article 31, paragraph 1, or article 32. According to the commentary, the practice of the international organization as such "can, at a minimum, be conceived as a supplementary means of interpretation under article 32," but writers also largely agree that it can be "relevant for the determination of the object and purpose of the treaty, including the function of the international organization concerned...."65

Paragraph 4 states that paragraphs 1 to 3 are without prejudice to any "relevant rules of the organization," a point that reflects VCLT article $5 .{ }^{66}$

\section{Protection of the Environment in Relation to Armed Conflicts}

The Commission considered the second report on the protection of the environment in relation to armed conflict by the special rapporteur, Marie G. Jacobsson (Sweden). ${ }^{67}$ Whereas the first report focused on rules of international law that operate in relation to the environment before armed conflict arises, the second report focused on rules of international law that apply once the armed conflict breaks out. In light of these two reports, introductory provisions proposed by the special rapporteur, along with a series of draft "principles," 68 were referred to the drafting committee, which completed work on them during the sixty-seventh session (there was, however, insufficient time for the Commission to approve these provisions with commentaries). An initial provision on "scope" simply provides: "The present draft principles apply to the protection of the environment before, during or after an armed conflict." A second provision on "purpose" states: "The present draft principles are aimed at enhancing the protection of the environment in relation to armed conflict, including through preventive measures for minimizing damage to the environment during armed conflict and through remedial

\footnotetext{
${ }^{64}$ Id. at $96-98$.

${ }^{65} \mathrm{Id}$. at $98-102$.

${ }^{66} \mathrm{Id}$. at $102-03$.

${ }^{67}$ International Law Commission, Second Report on the Protection of the Environment in Relation to Armed Conflicts, UN Doc. A/CN.4/685 (May 28, 2015) (prepared by Special Rapporteur Marie Jacobsson). For prior discussion of this topic, see Murphy, Sixty-Sixth Session, supra note 3, at 143.

68 The Commission has adopted a project consisting of "principles" on only three prior occasions. In 1950, the Commission completed seven Principles of International Law Recognized in the Charter of the Nürnberg Tribunal and in the Judgment of the Tribunal, with commentaries, which were designed to influence the future development of a draft code and creation of an international criminal court. See 1950 Report, supra note 14, at 374-78. In 2006, the Commission adopted the Draft Principles on the Allocation of Loss in the Case of Transboundary Harm Arising Out of Hazardous Activities, with commentaries, in an effort to promote (but not compel) harmonization of national laws through recommendations rather than hard law. See Report of the International Law Commission on the Work of its Fifty-Eighth Session, UN GAOR, 61st Sess., Supp. No. 10, at 110, para. 67, UN Doc. A/61/10 (2006) [hereinafter 2006 Report]; see also Report of the International Law Commission on the Work of its Fifty-Sixth Session, UN GAOR, 59th Sess., Supp. No. 10, at 160(14), UN Doc. A/59/10 (2004). Also in 2006, the Commission transformed what had originally been envisaged as draft articles into the Guiding Principles Applicable to Unilateral Declarations of States Capable of Creating Legal Obligations, with commentaries. See 2006 Report, supra, at 369, para. 177.
} 
measures.",69

The actual principles then begin in Part One on "Preventive Measures" with an initial principle I-(x) on "Designation of protected zones," which reads: "States should designate, by agreement or otherwise, areas of major environmental and cultural importance as protected zones." ${ }^{, 70}$ There are as yet no other principles in this Part I, but it is expected that the special rapporteur in her third report will propose additional principles, perhaps drawing upon proposals that were contained in her first report.

Part Two on "Draft principles applicable during armed conflict" contains at present five draft principles. They read as follows:

Draft principle II-1

General protection of the [natural] environment during armed conflict

1. The [natural] environment shall be respected and protected in accordance with applicable international law and, in particular, the law of armed conflict.

2. Care shall be taken to protect the [natural] environment against widespread, long-term and severe damage.

3. No part of the [natural] environment may be attacked, unless it has become a military objective.

Draft principle II-2

Application of the law of armed conflict to the environment

The law of armed conflict, including the principles and rules on distinction, proportionality, military necessity and precautions in attack, shall be applied to the [natural] environment, with a view to its protection.

Draft principle II-3

Environmental considerations

Environmental considerations shall be taken into account when applying the principle of proportionality and the rules on military necessity.

Draft principle II-4

Prohibition of reprisals

Attacks against the [natural] environment by way of reprisals are prohibited.

\footnotetext{
${ }^{69}$ International Law Commission, Statement of the Chairman of the Drafting Committee, Mr. Mathias Forteau, "Protection of the environment in relation to armed conflicts," annex (July 30, 2015), available at http://legal.un.org/docs/?path=../ilc/documentation/english/statements/2015_dc_chairman_statement_peac.pdf\&lang $=\mathrm{EF}$.

${ }^{70} I d$.
} 


\section{Principle II-5}

Protected zones

An area of major environmental and cultural importance designated by agreement as a protected zone shall be protected against any attack, as long as it does not contain a military objective. ${ }^{71}$

The word "natural" is in brackets for the time being because that word is used in relevant treaties on the law of armed conflict, but often is not used in more general treaties addressing international environmental law. Perhaps the most controversial of these principles is draft principle II-4 on reprisals, which repeats verbatim Article 55, paragraph 2, of the Protocol Additional to the Geneva Conventions of 12 August 1949, and relating to the Protection of Victims of International Armed Conflicts (Protocol I). ${ }^{72}$ The 174 states parties to Protocol I that have not filed a reservation or declaration relating to this provision are bound to such a rule, but several states parties reserved their position on this provision, such as the United Kingdom. ${ }^{73}$ States that are not a party to Protocol I, such as India, Iran, Israel, Pakistan, Turkey, and the United States, are not bound to Article 55, paragraph 2, and the United States has repeatedly stated that it does not regard the rule to be a part of customary international law. ${ }^{74}$ In the Nuclear

\footnotetext{
${ }^{71} I d$.

72 June 8, 1977, 1125 UNTS 3.

${ }^{73}$ In connection with the deposit of its instrument of ratification to Protocol I, the United Kingdom stated:
}

If an adverse party makes serious and deliberate attacks, in violation of Article 51 or Article 52 against the civilian population or civilians or against civilian objects, or, in violation of Articles 53, 54 and 55, on objects or items protected by those Articles, the United Kingdom will regard itself as entitled to take measures otherwise prohibited by the Articles in question to the extent that it considers such measures necessary for the sole purpose of compelling the adverse party to cease committing violations under those Articles, but only after formal warning to the adverse party requiring cessation of the violations has been disregarded and then only after a decision taken at the highest level of government.

United Kingdom, Statement on Ratification of AP I, 2020 UNTS 75, 77-78 (1998); see also UK MINISTRY OF DEF., THE MANUAL OF THE LAW OF ARMED CONFLICT 421 (§ 16.19.2) (2004) ("This means that reprisals taken in accordance with the statement are permissible by and against the United Kingdom."); YORAM DINSTEIN, THE CONDUCT OF HOSTILITIES UNDER THE LAW OF INTERNATIONAL ARMED CONFLICT 226 (2004) (noting that the UK declaration-reservation has not elicited any objections); FRITS KALSHOVEN \& LIESBETH ZEGVELD, CONSTRAINTS ON THE WAGING OF WAR: AN INTRODUCTION TO INTERNATIONAL HUMANITARIAN LAW 146 (3d ed., 2001) (finding that the U.K. declaration-reservation "is an accurate formulation of the requirements international law traditionally sets for recourse to belligerent reprisals"); Christopher J. Greenwood, Belligerent Reprisals in the Jurisprudence of the International Criminal Tribunal for the Former Yugoslavia, in INTERNATIONAL AND NATIONAL PROSECUTION OF CRIMES UNDER INTERNATIONAL LAW 539, 550-56 (Horst Fischer et al. eds., 2001).

${ }^{74}$ For the United States, see Michael J. Matheson, Deputy Legal Adviser, U.S. Dep't of State, Remarks at the Sixth Annual American Red Cross-Washington College of Law Conference on International Humanitarian Law, The United States Position on the Relation of Customary International Law to the 1977 Protocols Additional to the 1949 Geneva Conventions, in 2 AM. U. J. INT’L L. \& POL'Y 419, 426 \& n.33 (1987) (“On the other hand, we do not support the prohibition on reprisals in article 51 and subsequent articles, again for reasons that Judge Sofaer will explain later, and do not consider it a part of customary law."); Abraham D. Sofaer, Legal Adviser, U.S. Dep't of State, Position of the United States on Current Law of War Agreements, 2 AM. U. J. INT'L L. \& POL'Y 460, 469 (1987). In 1995, the United States also described the prohibition on reprisals against the natural environment as "among the new rules established by the Protocol" and that "Additional Protocol I to the 1949 Geneva Conventions contains a number of new rules on means and methods of warfare, which of course apply only to States that ratify 
Weapons Advisory Opinion, the International Court recognized that “Articles 35, paragraph 3, and 55 of Additional Protocol 1 provide additional protection for the environment," and that one of those protections was "the prohibition of attacks against the natural environment by way of reprisals." 75 Yet the Court cautiously concluded its statement by saying that: "These are powerful constraints for all the States having subscribed to these provisions." 76 Among other things, the ICRC's study of customary international humanitarian law, reflecting on Articles 52 to 56 of Protocol I and on the practice of a variety of states, asserts:

While the vast majority of States have now specifically committed themselves not to take reprisal action against such [protected] objects, because of existing contrary practice, albeit very limited, it is difficult to conclude that there has yet crystallised a customary rule specifically prohibiting reprisals against these civilian objects in all situations. ${ }^{77}$

Further, to the extent that the Commission's draft principles are addressing all armed conflict, including non-international armed conflict, it must be noted that there is no specific prohibition on belligerent reprisals in either common Article 3 to the 1949 Geneva Conventions or in the Protocol Additional to the Geneva Conventions of 12 August 1949, and Relating to the Protection of Victims of Non-International Armed Conflicts (Protocol II). ${ }^{78}$ Presumably in light

Protocol I. (For example, the provisions on reprisals and the protection of the environment are new rules that have not been incorporated into customary law.)" Written Statement of the Government of the United States of America, June 20, 1995, at 25, 31, in Legality of the Threat or Use of Nuclear Weapons, http://www.icjcij.org/docket/files/95/8700.pdf. The 2015 U.S. Department of Defense Law of War Manual, with respect to Articles 35(3) and 55 of Additional Protocol I, states that: "The United States has not accepted these provisions and has repeatedly expressed the view that these provisions are 'overly broad and ambiguous and "not a part of customary law.",") U.S. DEP’T OF DEF., LAW OF WAR MANUAL 354 (\$ 6.10.3.1) (2015). Further, the Manual asserts that "AP I's provisions on reprisal are counter-productive and that they remove a significant deterrent that protects civilians and war victims on all sides of a conflict." Id. at 1098 (\$ 18.18.3.4).

${ }^{75}$ Legality of the Threat or Use of Nuclear Weapons, supra note 11, at 242, para. 31.

${ }^{76}$ Id. (emphasis added); see also UN Security Council, Final Report of the Commission of Experts Established Pursuant to Security Council Resolution 780 (1992), at 19 (§ 66), UN Doc. S/1994/674 (1994) (“In international armed conflicts to which the four Geneva Conventions and Additional Protocol I apply, lawful reprisals...must be directed exclusively against combatants or other military objectives subject to the limitations contained in the Geneva Conventions, Protocol I and customary international law of armed conflicts. In international armed conflicts where Additional Protocol I does not apply, reprisals may be directed against a much wider category of persons and objects, but subject to the limitations of customary international law of armed conflicts.") (emphasis added); Fausto Pocar, To What Extent is Protocol I Customary International Law?, in LEGAL AND ETHICAL LESSONS OF NATO'S Kosovo CAmpaign 337, 349 (Andru E. Wall ed., 2002) (Naval War Coll., International Law Studies vol. 78, 2002):

It is well known that the controversy on this matter has been and still is important, and different views have been expressed both at the Geneva Diplomatic Conference where Protocol I was negotiated and subsequently. The dominant view is probably that the provisions of Protocol I [on reprisals] neither reflect pre-existing customary law nor have subsequently reached that nature, but contain significant developments in this regard.

77 JEAN-MARIE HENCKAERTS \& LOUISE DOSWALD-BECK, 1 CUSTOMARY INTERNATIONAL HUMANITARIAN LAW: RULES 525 (2005) (citation omitted).

78 June 8, 1977, 1125 UNTS 609. The late A.P.V. Rogers noted that, at the 1977 diplomatic conference, some delegations expressed the view that the rules on belligerent reprisals only applied to international armed conflict, and he concluded that the existence of the doctrine of belligerent reprisals "in the law of internal armed conflict, where the treaty rules are silent on the issue, must remain a matter of debate." A.P.V. ROGERS, LAW ON THE BATTLEFIELD 234-35 (2d ed. 2004). 
of such factors, the special rapporteur in her concluding remarks to the Commission's plenary on the issue of reprisals "stressed that the purpose of the topic was not to establish customary rules but to set a standard.",79

The special rapporteur's third report in 2016 is expected to focus on post-conflict measures, such as cooperation, sharing of information, and best practices, as well as reparative measures, but will also likely attempt to fill out all the remaining provisions for this project.

\section{Immunity of State Officials from Foreign Criminal Jurisdiction}

The Commission considered the fourth report on the "immunity of State officials from foreign criminal jurisdiction" by its second special rapporteur for this topic, Concepción Escobar Hernández (Spain). ${ }^{80}$ After debating the report, the Commission's Drafting Committee provisionally adopted draft Article 2(f), which defines act performed in an official capacity to mean "any act performed by a State official in the exercise of State authority," 81 and draft Article 6 on "Scope of immunity ratione materiae," which reads as follows:

1. State officials enjoy immunity ratione materiae only with respect to acts performed in an official capacity.

2. Immunity ratione materiae with respect to acts performed in an official capacity continues to subsist after the individuals concerned have ceased to be State officials.

3. Individuals who enjoyed immunity ratione personae in accordance with draft article 4, whose term of office has come to an end, continue to enjoy immunity with respect to acts performed in an official capacity during such term of office. ${ }^{82}$

In her fifth report, the special rapporteur intends to address "limits and exceptions to immunity of State officials from foreign criminal jurisdiction." 83 A subsequent and final report will then consider the procedural aspects of the topic. ${ }^{84}$

\section{Provisional Application of Treaties}

The Commission considered the third report on the provisional application of treaties by the special rapporteur, Juan Manuel Gómez-Robledo (Mexico), ${ }^{85}$ which proposed six initial draft

\footnotetext{
${ }^{79} 2015$ Report, supra note 1, at 114, para. 169.

${ }^{80}$ International Law Commission, Fourth Report on the Immunity of State Officials from Foreign Criminal Jurisdiction, UN Doc. A/CN.4/686 (May 29, 2015) (prepared by Special Rapporteur Concepción Escobar Hernández) [hereinafter Fourth Report on the Immunity of State Officials]. For prior discussion of this topic, see Murphy, Sixty-Sixth Session, supra note 3, at 139-40.

812015 Report, supra note 1 , at 116 , footnote 140.

${ }^{82}$ Id.

${ }^{83}$ See Fourth Report on the Immunity of State Officials, supra note 80, at 75, para. 134.

${ }^{84} \mathrm{Id}$. at 58 , para. 139.

${ }^{85}$ International Law Commission, Third Report on the Provisional Application of Treaties, UN Doc. A/CN.4/687* (June 5, 2015) (prepared by Special Rapporteur Juan Manuel Gómez-Robledo). For prior discussion of this topic, see Murphy, Sixty-Sixth Session, supra note 3, at 143-44.
} 
guidelines for this topic. After debate in the plenary, all six proposed guidelines were sent to the drafting committee, which only had sufficient time to adopt provisionally three draft guidelines. Draft guideline 1 on "scope" states that the "present draft guidelines concern the provisional application of treaties." Draft guideline 2 on "purpose" provides: "The purpose of the present draft guidelines is to provide guidance regarding the law and practice on the provisional application of treaties, on the basis of Article 25 of the Vienna Convention on the Law of Treaties and other rules of international law." Draft guideline 3 sets forth the "general rule," providing that a "treaty or a part of a treaty may be provisionally applied, pending its entry into force, if the treaty itself so provides, or if in some other manner it has been so agreed." 86

\section{Most-Favored-Nation Clause}

The Commission reconstituted the study group on the topic of the most-favored-nation (MFN) clause, under the chairmanship of Donald M. McRae (Canada). ${ }^{87}$ The group completed a final report summarizing its work on this topic since 2009. ${ }^{88}$ A final report considers developments in the law and practice since the adoption of the Commission's 1978 draft articles on MFN clauses with commentaries ${ }^{89}$ but does not propose any revision of those draft articles. The final report discusses, in particular, whether an MFN clause in a treaty may be invoked by an investor to obtain a more favorable dispute resolution provision existing in a comparator treaty (i.e., a different treaty between the host state and a third state) ${ }^{90}$ and, in that regard, analyzes case law since the Maffezini v. Spain award in $2000 .^{91}$ The final report does not declare that the Maffezini decision (which allowed an MFN clause to be invoked to obtain a more favorable dispute resolution provision) was either correct or incorrect but, rather, indicates a range of issues that should be considered whenever analyzing an MFN clause for such a purpose. For example, the text and context of the specific MFN clause at issue may point the analysis in one direction or the other. Further, the draft report indicates ways in which states have reacted to the Maffezini decision, such as by drafting MFN clauses that expressly provide that the clause does or does not apply to dispute resolution provisions. The Commission welcomed the report and commended it to the attention of the General Assembly. ${ }^{92}$

\section{FUTURE WORK AND ILC ELECTION IN 2016}

Since 2008, the Commission has considered the topic of the protection of persons in the event of disasters, guided by six reports submitted by the special rapporteur, Eduardo Valencia-

\footnotetext{
${ }^{86}$ International Law Commission, Statement of the Chairman of the Drafting Committee, Mr. Mathias Forteau, "Provisional application of treaties,"annex (Aug. 4, 2015), available at http://legal.un.org/docs/?path=../ilc/documentation/english/statements/2015_dc_chairman_statement_pat.pdf\&lang= $\mathrm{EF}$.

${ }^{87} 2015$ Report, supra note 1, at 17, para. 34. For prior discussion of this topic, see Murphy, Sixty-Sixth Session, supra note 3, at 144-45.

${ }^{88} 2015$ Report, supra note 1, at 147 (annex).

${ }^{89}$ See Report of the International Law Commission on the Work of Its Thirtieth Session, UN GAOR, 33rd Sess., Supp. No. 10, at 16-73, para. 74, UN Doc. A/33/10 (1978).

902014 Report, supra note 45, para. 257.

${ }^{91}$ Maffezini v. Kingdom of Spain, ICSID Case No. ARB/97/7, Decision of the Tribunal on Objections to Jurisdiction (Jan. 25, 2000).

${ }_{92} 2015$ Report, supra note 1, at 18, para. 41.
} 
Ospina (Colombia). ${ }^{93}$ During the sixty-sixth session in 2014, the Commission completed a full set of draft articles with commentaries, ${ }^{94}$ which were sent to the General Assembly for states to consider and comment upon orally or in writing by January 2016. Hence, it is expected that the Commission will return to the topic during the sixty-eighth session in 2016 and revise the draft articles with commentaries on second reading, taking into account the views received from states.

During the sixty-seventh session, the Commission moved the topic of jus cogens onto the current program of work and appointed Dire D. Tladi (South Africa) as special rapporteur. ${ }^{95}$ Consequently, it is expected that he will produce a first report for the sixty-eighth session in 2016.

The sixty-eighth session will mark the end of the current quinquennium of the Commission. A new Commission of 34 members will be elected by the UN General Assembly in the fall of 2016 to serve from 2017 until 2021.

\footnotetext{
${ }^{93}$ For prior discussion of this topic, see Murphy, Sixty-Sixth Session, supra note 3, at 132-35.

${ }^{94} 2014$ Report, supra note 45, at 84-138.

${ }^{95} 2015$ Report, supra note 1, at 138, para. 286.
} 